\title{
PENGARUH DISIPLIN BELAJAR DAN LINGKUNGAN TEMAN SEBAYA \\ TERHADAP PRESTASI BELAJAR MAHASISWA PROGRAM STUDI \\ PENDIDIKAN AKUNTANSI ANGKATAN 2009 FAKULTAS EKONOMI \\ UNIVERSITAS NEGERI YOGYAKARTA
}

\author{
Oleh : \\ Singgih Tego Saputro ${ }^{1}$ \\ Pardiman $^{2}$
}

\begin{abstract}
Abstrak
Penelitian ini bertujuan untuk mengetahui (1) Pengaruh Disiplin Belajar terhadap Prestasi Belajar mahasiswa Program Studi Pendidikan Akuntansi angkatan 2009 Fakultas Ekonomi Universitas Negeri Yogyakarta., (2) Pengaruh Lingkungan Teman Sebaya terhadap Prestasi Belajar mahasiswa Program Studi Pendidikan Akuntansi angkatan 2009 Fakultas Ekonomi Universitas Negeri Yogyakarta, (3) Pengaruh Disiplin Belajar dan Lingkungan Teman Sebaya secara besama-sama terhadap Prestasi Belajar mahasiswa Program Studi Pendidikan Akuntansi angkatan 2009 Fakultas Ekonomi Universitas Negeri Yogyakarta.

Populasi dalam penelitian ini adalah mahasiswa Program Studi Pendidikan Akuntansi angkatan 2009 dengan jumlah 117 mahasiswa, sehingga penelitian ini merupakan penelitian populasi. Pengumpulan data dengan metode kuesioner atau angket dan metode dokumentasi. Metode kuesioner untuk mengumpulkan data Disiplin Belajar dan Lingkungan Teman Sebaya, sedangkan metode dokumentasi untuk mengetahui Prestasi Belajar. Uji coba instrumen ini dilakukan terhadap 30 mahasiswa Program Studi Pendidikan Akuntansi Angkatan 2008 Fakultas Ekonomi Universitas Negeri Yogyakarta, analisis data yang digunakan adalah teknik analisis regresi sederhana untuk hipotesis pertama dan kedua serta analisis regresi ganda untuk hipotesis ketiga. Sebelum analisis data terlebih dahulu diadakan pengujian persyaratan analisis meliputi uji linieritas dan multikolinieritas.

Hasil penelitian ini adalah: (1) Terdapat pengaruh positif dan signifikan Disiplin Belajar terhadap Prestasi Belajar Mahasiswa Program Studi Pendidikan Akuntansi Angkatan 2009 Fakultas Ekonomi Universitas Negeri Yogyakarta yang ditunjukkan dengan nilai thitung lebih besar dari tabel yaitu: 7,780 > 1,984 dengan koefisien determinasi sebesar 0,345 yang artinya sebesar 34,5\% variabel ini mempengaruhi Prestasi Belajar. (2) Terdapat pengaruh positif dan signifikan Lingkungan Teman Sebaya terhadap Prestasi Belajar Mahasiswa Program Studi Pendidikan Akuntansi Angkatan 2009 Fakultas Ekonomi Universitas Negeri Yogyakarta yang ditunjukkan dengan nilai thitung lebih besar dari tabel yaitu: 5,097 > 1,984 dengan koefisien determinasi sebesar 0,184 yang artinya sebesar 18,4\% variabel ini mempengaruhi Prestasi Belajar. (3) Terdapat pengaruh positif dan signifikan Disiplin Belajar dan Lingkungan Teman Sebaya secara bersama-sama terhadap Prestasi Belajar Mahasiswa Program Studi Pendidikan Akuntansi Angkatan 2009 Fakultas Ekonomi Universitas Negeri Yogyakarta yang ditunjukkan dengan nilai $\mathrm{F}_{\text {hitung }}$ lebih besar dari $\mathrm{F}_{\text {tabel }}$ yaitu: 36,618 > 3,090

\footnotetext{
${ }^{1}$ Alumni Program Studi Pendidikan Akuntansi UNY

${ }^{2}$ Dosen Jurusan Pendidikan Akuntansi UNY
} 
pada taraf signifikansi 5\% dan koefisien determinasi sebesar 0,391 yang artinya sebesar $39,1 \%$ kedua variabel ini secara bersama-sama mempengaruhi Prestasi Belajar. Persamaan garis regresi $\mathrm{Y}=0,017 \mathrm{X}_{1}+0,007 \mathrm{X}_{2}+1,866$.

Kata Kunci : Prestasi Belajar, Disiplin Belajar, dan Lingkungan Teman Sebaya.

\section{A. PENDAhULUAN}

\section{Latar Belakang Masalah}

Pendidikan Pendidikan dipandang sebagai cara yang tepat untuk membentuk sumber daya manusia yang berkualitas untuk mendukung tercapainya tujuan pembangunan nasional. Melalui pendidikan, manusia mendapatkan pengetahuan, keterampilan, nilai dan sikap sehingga dapat berpikir lebih sistematis, rasional, dan kritis terhadap permasalahan yang dihadapi.

Menurut UU No. 20 Tahun 2003 tentang Sistem Pendidikan Nasional menyatakan bahwa : Pendidikan nasional berfungsi mengembangkan kemampuan dan membentuk watak serta peradaban bangsa yang bermartabat dalam rangka mencerdaskan kehidupan bangsa, bertujuan untuk mengembangkan potensi peserta didik agar menjadi manusia yang beriman dan bertaqwa kepada Tuhan Yang Maha Esa, berakhlak mulia, sehat, berilmu, cakap, kreatif, mandiri dan menjadi warga Negara yang demokratis dan bertanggung jawab.

Pendidikan dapat dikatakan berhasil apabila telah memenuhi tujuan pendidikan nasional. Pendidikan juga dikatakan berhasil apabila proses belajar mengajar dilaksanakan secara efektif dan efisien sehingga hasil belajar dapat dicapai dengan lebih optimal. Untuk mengetahui ketercapaian tingkat keberhasilan pendidikan, maka perlu diadakan evaluasi. Evaluasi artinya penilaian terhadap tingkat keberhasilan peserta didik mencapai tujuan yang telah ditetapkan dalam sebuah program (Muhhibin Syah, 2008: 141). Berdasarkan UU Sisdiknas No. 20 Tahun 2003 pasal 58 (1) evaluasi hasil belajar peserta didik dilakukan untuk memantau proses, kemajuan dan perbaikan hasil belajar peserta didik secara berkesinambungan. Hasil belajar dapat dapat diketahui dari prestasi belajar yang diperoleh oleh peserta didik. Prestasi belajar merupakan hasil dari pengukuran dan penilaian usaha belajar. Bukti keberhasilan dari seseorang setelah memperoleh pengalaman belajar atau mempelajari sesuatu merupakan Prestasi Belajar yang dicapai oleh peserta didik dalam waktu tertentu

Prestasi Belajar mahasiswa adalah hasil penilaian dari kegiatan belajar yang telah dilakukan dan merupakan bentuk perumusan akhir yang diberikan oleh dosen untuk melihat 


\section{Jurnal Pendidikan Akuntansi Indonesia, Vol. X, No. 1, Tahun 2012 \\ Singgih Tego Saputro \& Pardiman \\ Halaman $78-97$}

sampai di mana kemampuan mahasiswa yang dinyatakan dalam bentuk simbul, angka, huruf maupun kalimat yang dapat mencerminkan hasil yang sudah dicapai. Prestasi Belajar mahasiswa dapat dilihat dari Indeks Prestasi Kumulatif (IPK) yang diperoleh mahasiswa. Namun untuk mendapatkan Prestasi Belajar yang baik bukanlah hal yang mudah, tetapi membutuhkan usaha yang optimal.

Universitas Negeri Yogyakarta (UNY) sebagai salah satu Perguruan Tinggi di Indonesia yang memiliki sistem budaya kerja sinergis yang menghargai belajar, tanggung jawab kreatif dan nilai-nilai keadilan, kedamaian dan kesantunan dalam melaksanakan Tridharma Perguruan Tinggi, sehingga mampu menghasilkan tenaga kependidikan dan non kependidikan yang berkualitas unggul di dunia global. Program Studi Pendidikan Akuntansi merupakan salah satu program studi di Fakultas Ekonomi Universitas Negeri Yogyakarta dituntut untuk dapat menghasilkan sumber daya manusia yang berkualitas. Diterapkannya evaluasi keberhasilan studi empat semester pertama berupa Indeks Prestasi Kumulatif (IPK) minimum 2,0 dan jumlah Sistem Kredit Semester (SKS) minimum 40 di Program Studi Pendidikan Akuntansi, mencerminkan bahwa Prestasi Belajar merupakan merupakan salah satu indikator keberhasilan studi mahasiswa. Dengan Prestasi Belajar yang baik diharapkan mampu menggambarkan kualitas mahasiswa yang baik pula, apalagi sebagai calon guru yang harus mampu mencerdaskan generasi penerus bangsa.

Secara garis besar faktor-faktor yang mempengaruhi Prestasi Belajar mahasiswa pendidikan akuntansi dibedakan menjadi dua yaitu faktor internal dan faktor eksternal. Menurut Slameto (2010: 54), terdapat dua faktor yang mempengaruhi belajar yaitu faktor internal dan faktor eksternal. Faktor internal antara lain fisik/jasmani, kematangan fisik, kelelahan, psikologi berupa bakat, minat, kecerdasan, motivasi dan kemampuan kognitif maupun prestasi. Faktor eksternal meliputi lingkungan alam, lingkungan keluarga (cara orang tua mendidik, relasi antar anggota keluarga, suasana rumah, keadaan ekonomi keluarga, pengertian orang tua, latar belakang kebudayaan), lingkungan sekolah (metode mengajar, media pembelajaran, kurikulum, relasi guru dengan siswa, relasi siswa dengan siswa, disiplin sekolah, waktu sekolah, standar pelajaran di atas ukuran, metode belajar, tugas rumah), dan lingkungan masyarakat (kegiatan siswa dalam masyarakat, teman bergaul, bentuk kehidupan masyarakat). Baharuddin (2009:19) juga menjelaskan faktor eksternal dibedakan menjadi dua yaitu lingkungan sosial seperti lingkungan sosial sekolah yang di dalamnya termasuk guru, 


\section{Jurnal Pendidikan Akuntansi Indonesia, Vol. X, No. 1, Tahun 2012 \\ Singgih Tego Saputro \& Pardiman \\ Halaman $78-97$}

administrasi dan teman sebaya, lingkungan sosial masyarakat, dan lingkungan sosial keluarga seperti ketegangan keluarga, sifat-sifat orang tua, demografi keluarga, status sosial ekonomi sedangkan lingkungan nonsosial terdiri dari lingkungan alamiah, faktor instrumental, faktor materi pelajaran.

Faktor penting yang mempengaruhi Prestasi Belajar salah satunya adalah Disiplin Belajar. Di dalam pengelolaan pengajaran, disiplin merupakan suatu masalah penting. Tanpa adanya kesadaran akan keharusan melaksanakan aturan yang sudah ditentukan sebelumnya pengajaran tidak mungkin mencapai target yang maksimal. Menurut Slameto (2010:67) "Agar siswa belajar lebih maju, siswa harus disiplin baik di sekolah, di rumah, dan di perpustakaan".

Seorang mahasiswa perlu memiliki sikap disiplin dengan melakukan latihan yang memperkuat dirinya sendiri untuk selalu terbiasa patuh dan mempertinggi daya kendali diri. Disiplin Belajar adalah pengendalian diri mahasiswa terhadap bentuk-bentuk aturan baik tertulis maupun tidak tertulis yang telah diterapkan oleh mahasiswa yang bersangkutan maupun berasal dari luar serta bentuk kesadaran akan tugas dan tanggung jawabnya sebagai pelajar, baik disiplin di rumah maupun di kampus dengan tidak melakukan sesuatu yang dapat merugikan tujuan dari proses belajarnya. Menurut Suharsimi (2003 :114) "disiplin merupakan sesuatu yang berkenaan dengan pengendalian diri seseorang terhadap bentukbentuk aturan di mana aturan tersebut diterapkan oleh orang yang bersangkutan maupun berasal dari luar”. Sikap disiplin yang timbul dari kesadarannya sendiri akan dapat lebih memacu dan tahan lama dibandingkan dengan sikap disiplin yang timbul karena adanya pengawasan dari orang lain. Mahasiswa yang memiliki disiplin yang tinggi akan belajar dengan baik dan teratur sehingga akan menghasilkan prestasi yang baik.

Lingkungan Teman Sebaya juga merupakan faktor yang mempengaruhi Prestasi Belajar Mahasiswa Program Studi Pendidikan Akuntansi Angkatan 2009 Fakultas Ekonomi Universitas Negeri Yogyakarta. Lingkungan Teman Sebaya merupakan lingkungan dimana terjadinya suatu interaksi yang intensif dan cukup teratur dengan orang-orang yang mempunyai kesamaan dalam usia dan status, yang memberikan dampak atau pengaruh positif maupun negatif yang dikarenakan interaksi di dalamnya.

Lingkungan Teman Sebaya yang merupakan lingkungan bersentuhan langsung dengan kehidupan mahasiswa setiap harinya. Slavin (2008:98) mengungkapkan bahwa 


\section{Jurnal Pendidikan Akuntansi Indonesia, Vol. X, No. 1, Tahun 2012 Singgih Tego Saputro \& Pardiman \\ Halaman $78-97$}

"Lingkungan Teman Sebaya merupakan suatu interaksi dengan orang-orang yang mempunyai kesamaan dalam usia dan status". Intensitas pertemuan antar mahasiswa di kampus yang tinggi memiliki pengaruh yang besar dalam suasana perkuliahan. Teman sebaya mampu memberikan motivasi sekaligus suasana yang membangun apabila berada sedang di dalam kelas. Mahasiswa juga lebih merasa nyaman jika belajar ataupun bertanya mengenai materi kuliah dengan teman sebaya karena apabila bertanya dengan dosen biasanya akan muncul suatu ketakutan tersendiri. Dengan adanya Disiplin Belajar yang tinggi dan Lingkungan Teman Sebaya yang mendukung maka Prestasi Belajar akan meningkat dan begitu juga sebaliknya jika Disiplin Belajar rendah dan Lingkungan Teman Sebaya yang kurang mendukung maka Prestasi Belajar akan rendah. Sehingga kedua faktor yang mempengaruhi Prestasi Belajar tersebut mempunyai andil yang cukup besar dalam kegiatan belajar.

Prestasi Belajar Mahasiswa Program Studi Pendidikan Akuntansi Angkatan 2009 Fakultas Ekonomi Universitas Negeri Yogyakarta belum seluruhnya mencapai hasil yang optimal. Dengan diterapkannya evaluasi keberhasilan studi untuk empat semester pertama ternyata masih ada satu mahasiswa yang terkena Drop Out (DO) karena tidak mencapai Indeks Prestasi Kumulatif (IPK) minimum tercapai untuk empat semester pertama sebesar 2,00 dan jumlah Sistem Kredit Semester (SKS) minimum sebesar 40.

Adanya kenyataan bahwa masih ada mahasiswa yang terkena Drop Out (DO) karena tidak mencapai Indeks Prestasi Kumulatif (IPK) minimum dan jumlah Sistem Kredit Semester (SKS) minimum sebesar 40 maka berbagai usaha perlu dilakukan untuk memperbaiki kualitas pendidikan agar Prestasi Belajar mahasiswa Pendidikan Akuntansi menjadi optimal. Untuk mengatasi hal tersebut perlu ditelusuri faktor-faktor yang mempengaruhi Prestasi Belajar mahasiswa Program Studi Pendidikan Akuntansi, diharapkan pada akhirnya masalah-masalah tersebut dapat dipecahkan dan mahasiswa dapat mencapai Prestasi Belajar yang lebih baik.

Berdasarkan observasi yang telah dilakukan, ternyata masih saja terdapat mahasiswa yang kurang disiplin dalam hal belajar maupun perkuliahan. Fenomena SKS atau Sistem Kebut Semalam masih menjadi primadona dalam cara belajar mahasiswa Pendidikan Akuntansi angkatan 2009. Baik itu dalam hal mengerjakan tugas ataupun menghadapi ujian yang deadline-nya esok hari sehingga hasil yang didapat kurang maksimal. Ketidakdisiplinan 
juga terlihat dalam hal menghadiri perkuliahan, fenomena terlambat atau memanfaatkan $25 \%$ ijin tidak mengikuti kuliah masih menghiasi suasana perkuliahan meskipun tidak ada alasan kuat untuk tidak menghadiri perkuliahan padahal dosen menerapkan presensi kedatangan mahasiswa menjadi salah satu indikator pemberian nilai.

Anggapan mahasiswa mengenai mata kuliah yang rumit dan terlalu sulit juga menyebabkan mahasiswa kurang termotivasi untuk belajar. Hal ini menyebabkan minat mahasiswa untuk belajar menjadi kurang dan Prestasi Belajar mahasiswa menjadi kurang optimal.

Kondisi lain juga terlihat pada pelayanan Pembimbingan Akademik Mahasiswa, melihat dari manfaatnya yang cukup dominan, di mana dosen sebagai pemberi motivator, ternyata pada kenyataannya pemanfaatan layanan Pembimbingan Akademik oleh mahasiswa Program Studi Pendidikan Akuntansi belum optimal. Sebagian mahasiswa melakukan bimbingan dengan Pembimbing Akademik hanya sebatas untuk pengisian KRS.

Lingkungan Teman Sebaya juga mempengaruhi Prestasi Belajar Mahasiswa Program Studi Pendidikan Akuntansi Angkatan 2009 Fakultas Ekonomi Universitas Negeri Yogyakarta. Hal ini dapat dilihat dari kenyataan yang ada saat ini, banyak mahasiswa yang lebih banyak bergantung dalam hal-hal negatif dengan teman sebayanya seperti tidak saling mengingatkan dalam belajar atau bercanda pada saat perkuliahan, banyaknya mahasiswa yang jarang mengerjakan tugas karena ikut-ikutan temannya, sebagian mahasiswa lebih asyik mengobrol dengan teman sebelahnya daripada mendengarkan dosen yang sedang menjelaskan di depan kelas.

Berdasarkan latar belakang masalah di atas, terdapat keterkaitan antara Disiplin Belajar dan Lingkungan Teman Sebaya terhadap Prestasi Belajar mahasiswa. Berdasarkan pengamatan tersebut, peneliti tertarik untuk meneliti masalah ini ke dalam skripsi dengan judul "Pengaruh Disiplin Belajar dan Lingkungan Teman Sebaya terhadap Prestasi Belajar Mahasiswa Program Studi Pendidikan Akuntansi Angkatan 2009 Fakultas Ekonomi Universitas Negeri Yogyakarta”.

\section{Masalah Penelitian}

Berdasarkan pembatasan masalah di atas, maka dapat dirumuskan permasalahan sebagai berikut : 
a) Bagaimanakah pengaruh Disiplin Belajar terhadap Prestasi Belajar mahasiswa Program Studi Pendidikan Akuntansi angkatan 2009 Fakultas Ekonomi Universitas Negeri Yogyakarta?

b) Bagaimanakah pengaruh Lingkungan Teman Sebaya terhadap Prestasi Belajar mahasiswa Program Studi Pendidikan Akuntansi angkatan 2009 Fakultas Ekonomi Universitas Negeri Yogyakarta?

c) Bagaimanakah pengaruh Disiplin Belajar dan Lingkungan Teman Sebaya secara bersama-sama terhadap Prestasi Belajar mahasiswa Program Studi Pendidikan Akuntansi angkatan 2009 Fakultas Ekonomi Universitas Negeri Yogyakarta?

\section{Tujuan Penelitian}

Berdasarkan rumusan masalah di atas dapat diketahui tujuan dari penelitian yaitu:

a) Mengetahui pengaruh Disiplin Belajar dan Lingkungan Teman Sebaya secara sendirisendiri terhadap Prestasi Belajar mahasiswa Program Studi Pendidikan Akuntansi angkatan 2009 Fakultas Ekonomi Universitas Negeri Yogyakarta.

b) Mengetahui pengaruh Disiplin Belajar dan Lingkungan Teman Sebaya secara bersamasama terhadap Prestasi Belajar mahasiswa Program Studi Pendidikan Akuntansi angkatan 2009 Fakultas Ekonomi Universitas Negeri Yogyakarta.

\section{Kajian Pustaka}

a) Prestasi Belajar

Prestasi belajar adalah hasil dari pengukuran dan penilaian usaha belajar. Seperti yang dinyatakan oleh Sutratinah Tirtonegoro (2001: 43) bahwa "prestasi belajar adalah penilaian hasil usaha kegiatan yang dinyatakan dalam bentuk simbul, angka, huruf maupun kalimat yang dapat mencerminkan hasil yang sudah dicapai oleh setiap anak dalam periode tertentu".

Prestasi Belajar adalah hasil penilaian dari kegiatan belajar yang telah dilakukan dan merupakan bentuk perumusan akhir yang diberikan oleh dosen untuk melihat sampai di mana kemampuan mahasiswa yang dinyatakan dalam bentuk simbul, angka, huruf maupun kalimat yang dapat mencerminkan hasil yang sudah dicapai. 


\section{b) Disiplin Belajar}

Menurut Suharsimi (2003:114) “disiplin merupakan sesuatu yang berkenaan dengan pengendalian diri seseorang terhadap bentuk-bentuk aturan di mana aturan tersebut diterapkan oleh orang yang bersangkutan maupun berasal dari luar”. Menurut Slameto (2010: 67) "Agar siswa belajar lebih maju, siswa harus disiplin baik di sekolah, di rumah, dan di perpustakaan".

\section{c) Lingkungan Teman Sebaya}

Menurut Slavin (2008:98) "Lingkungan Teman Sebaya merupakan suatu interaksi dengan orang-orang yang mempunyai kesamaan dalam usia dan status".

\section{B. Metode Penelitian}

1. Jenis Penelitian

$>$ Penelitian ini termasuk penelitian ex-post facto

$>$ Penelitian merupakan penelitian kausal komparatif

$>$ Penelitian ini termasuk penelitian populasi

$>$ Pendekatan yang digunakan dalam analisis ini menggunakan pendekatan kuantitatif

\section{Subjek Penelitian}

Populasi dalam penelitian ini adalah mahasiswa Program Studi Pendidikan Akuntansi angkatan 2009 dengan jumlah 117 mahasiswa yang terbagi dalam 3 kelas.

Tabel 1. Perincian Jumlah Populasi Penelitian

\begin{tabular}{|c|c|}
\hline Kelas & Jumlah \\
\hline Subsidi & 48 mahasiswa \\
\hline Swadana & 54 mahasiswa \\
\hline Internasional & 15 mahasiswa \\
\hline Total & 117 mahasiswa \\
\hline
\end{tabular}

\section{Teknik Pengumpulan Data}

Teknik pengumpulan data yang digunakan dalam penelitian ini adalah kuesioner dan dokumentasi. 


\section{Teknik Analisis Data}

Dalam pengolahan data penelitian ini, diperlukan suatu rancangan analisis. Langkah untuk menganalisis data tersebut menggunakan perhitungan statistik. Namun, sebelum melakukan analisis data terlebih dahulu diuji beberapa prasyarat analisis agar kesimpulan yang diperoleh memenuhi syarat.

a) Uji Prasyarat Analisis Data

1) Uji Linieritas

$$
F_{\text {reg }}=\frac{R K_{\text {reg }}}{R K_{\text {res }}}
$$

Keterangan:

$F_{r e g} \quad=$ Harga $\mathrm{F}$ untuk garis regresi

$R K_{\text {reg }} \quad=$ Rerata kuadrat regresi

$R K_{\text {res }} \quad=$ Rerata kuadrat residu

(Sutrisno Hadi, 2004 : 14)

\section{2) Uji Multikolinieritas}

$$
\begin{array}{ll}
r_{x_{1} x_{2}}=\frac{N \sum X_{1} X_{2}-\left(\sum X_{1}\right)\left(\sum X_{2}\right)}{\sqrt{\left(N \sum X_{1}{ }^{2}-\left(\sum X_{1}\right)^{2}\right)\left(N \sum X_{2}{ }^{2}-\left(\sum X_{2}\right)^{2}\right)}} \\
r_{x_{1} x_{2}} & =\text { koefisien korelasi antara } X_{1} \text { dan } X_{2} \\
\sum X_{1} & =\text { jumlah variabel } X_{1} \\
\sum X_{2} & =\text { jumlah variabel } X_{2} \\
\sum X_{1} X_{2} & =\text { jumlah perkalian antara } X_{1} \text { dan } X_{2} \\
\left(\sum X_{1}\right)^{2} & =\text { jumlah variabel } X_{1} \text { dikuadratkan } \\
\left(\sum X_{2}\right)^{2} & =\text { jumlah variabel } X_{2} \text { dikuadratkan } \\
N & =\text { jumlah responden }
\end{array}
$$

(Suharsimi Arikunto, 2010:213)

\section{b) Pengujian Hipotesis}

\section{Analisis Regresi Sederhana}

1) Membuat Garis Linear Sederhana

$$
Y=a X+K
$$

Keterangan :

$\mathrm{Y}=$ Kriterium

$\mathrm{a}=$ Bilangan koefisien prediktor

$\mathrm{X}=$ Prediktor

$\mathrm{K}=$ Bilangan konstan 
(Sutrisno Hadi , 2004:5)

2) Mencari koefisien determinasi $\left(r^{2}\right)$ antara prediktor $X_{1}, X_{2}$, dan $X_{3}$ dengan $Y$ dengan rumus sebagai berikut:

$$
\begin{aligned}
& r_{(1)}^{2}=\frac{a_{1} \sum x_{1} y}{\sum y^{2}} \\
& r_{(2)}^{2}=\frac{a_{2} \sum x_{2} y}{\sum y}
\end{aligned}
$$

Keterangan:

$\mathrm{r}_{(1,2)}^{2} \quad=$ koefisien determinasi antara $\mathrm{Y}$ dengan $\mathrm{X}_{1}$ dan $\mathrm{X}_{2}$

$\sum \mathrm{x}_{1} \mathrm{y} \quad=$ jumlah produk antara $\mathrm{X}_{1}$ dengan $\mathrm{Y}$

$\sum \mathrm{x}_{2} \mathrm{y} \quad=$ jumlah produk antara $\mathrm{X}_{2}$ dengan $\mathrm{Y}$

$\mathrm{a}_{1} \quad=$ koefisien prediktor $\mathrm{X}_{1}$

$\mathrm{a}_{2} \quad=$ koefisien prediktor $\mathrm{X}_{2}$

$\sum \mathrm{y}^{2} \quad=$ jumlah kuadrat kriterium $\mathrm{Y}$

(Sutrisno, 2004: 22)

3) Menguji Signifikasi Regresi Linear Sederhana

Untuk menguji signifikasi digunakan uji t statistik. Uji t dilakukan untuk menguji signifikasi konstanta dari setiap variabel dependen.

$$
t=\frac{r(\sqrt{n-2})}{\left(\sqrt{1-r^{2}}\right)}
$$

Keterangan:

$\mathrm{t}=\mathrm{t}$ hitung

$\mathrm{r} \quad=$ koefisien korelasi

$\mathrm{n} \quad=$ jumlah responden

(Sugiyono, 2007: 230)

\section{Analisis Regresi Ganda}

1) Membuat persamaan garis dengan kedua prediktor, dengan rumus:

$$
Y=a_{1} x_{1}+a_{2} x_{2}+K
$$

Keterangan :

$\mathrm{Y}=$ Kriterium

$a \quad=$ Koefisien Prediktor

$\mathrm{X}=$ Prediktor

$\mathrm{K}=$ Bilangan Konstanta

(Sutrisno Hadi, 2004: 18)

2) Mencari koefisien korelasi ganda antara presiktor $X_{1}, X_{2}$ dengan kriterium $Y$, dengan menggunakan rumus : 


$$
r^{2}(1,2)=\frac{\left(a_{1} \sum x_{1} y\right)+\left(a_{2} \sum x_{2} y\right)}{\sum y^{2}}
$$

Keterangan :

$\mathrm{r}(1,2)=$ Koefisien determinasi antara $\mathrm{y}$ dengan $\mathrm{x}_{1}$ dan $\mathrm{x}_{2}$

$\mathrm{a}_{1} \quad=$ Koefisien prediktor $\mathrm{x}_{1}$

$\mathrm{a}_{2} \quad=$ Koefisin prediktor $\mathrm{x}_{2}$

$\sum \mathrm{x}_{1} \mathrm{y} \quad=$ Jumlah produk antara $\mathrm{x}_{1}$ dengan $\mathrm{y}$

$\sum \mathrm{x}_{2} \mathrm{y}=$ Jumlah produk antara $\mathrm{x}_{2}$ dengan $\mathrm{y}$

$\sum \mathrm{y} \quad=$ Jumlah kuadrat kriterium

(Sutrisno Hadi , 2004 : 22)

3) Untuk menguji keberartian regresi ganda diuji dengan harga $F$ dengan rumus :

$$
F_{\text {reg }}=\frac{R^{2}(N-m-1)}{m\left(1-R^{2}\right)}
$$

Keterangan :

$$
\begin{array}{ll}
F_{\text {reg }} & =\text { Harga } \mathrm{F} \text { garis regresi } \\
\mathrm{N} & =\text { Rerata kuadrat garis regresi } \\
\mathrm{m} & =\text { Kuadrat residu } \\
\mathrm{R} & =\text { Koefisien korelasi antara kriterium dengan prediktor }
\end{array}
$$

(Sutrisno Hadi, 2004:23)

4) Mengetahui seberapa besar sumbangan setiap variabel terhadap kriterium digunakan rumus.

a. Sumbangan Relatif (SR\%)

$$
\mathrm{SR} \%=\frac{a \sum \mathrm{XY}}{{ }^{\mathrm{K}} \text { Reg }} \mathrm{x} 100 \%
$$

Keterangan :

SR $\%=$ Sumbangan relatif dari suatu prediktor

$\mathrm{a}=$ Koefisien prediktor

$\sum \mathrm{xy} \quad=$ Jumlah produk $\mathrm{x}$ dan $\mathrm{y}$

$\mathrm{JK}_{\text {Reg }} \quad=$ Jumlah kuadarat regresi

(Sutrisno Hadi, 2004: 39)

b. Sumbangan Efektif (SE \%)

Sumbangan efektif dapat dihitung dengan menggunakan rumus:

$S E \%=S R \% \times R^{2}$

Keterangan:

SE $\%=$ Sumbangan efektif

SR $\%=$ Sumbangan relatif

$\mathrm{R}^{2} \quad=$ Koefisien determinasi

(Sutrisno Hadi, 2004: 39) 


\section{Hasil Penelitian dan Pembahasan}

1. Pengujian Instrumen

a) Uji Validitas

Berdasarkan hasil perhitungan bantuan komputer program SPSS versi 16.0 dapat diperoleh hasil sebagai berikut:

1) Uji Validitas Alat Ukur Disiplin Belajar

Berdasarkan indikator-indikator dari variabel Disiplin Belajar dikembangkan menjadi 25 butir pernyataan. Setelah dilakukan uji validitas didapat 22 butir pernyataan yang tergolong valid dan 3 butir pernyataan yang tergolong gugur/tidak valid yaitu butir pernyataan nomor 4,8 dan 14 .

2) Uji Validitas Alat Ukur Lingkungan Teman Sebaya

Berdasarkan indikator-indikator dari variabel Lingkungan Teman Sebaya dikembangkan menjadi 20 butir pernyataan. Setelah dilakukan uji validitas didapat 19 butir pernyataan yang tergolong valid dan 1 butir pernyataan yang tergolong gugur/tidak valid yaitu butir pernyataan nomor 6 .

\section{b) Uji Reliabilitas}

Setelah dilakukan uji reliabilitas dengan menggunakan bantuan komputer SPSS 16.0 For Windows diperoleh hasil sebagai berikut:

1) Instrumen Disiplin Belajar memiliki koefisien reliabilitas sebesar 0,901 sehingga instrumen dikatakan reliabel dengan tingkat keterandalan sangat tinggi.

2) Instrumen Lingkungan Teman Sebaya memiliki koefisien reliabilitas sebesar 0,884 sehingga instrumen dikatakan reliabel dengan tingkat keterandalan sangat tinggi.

\section{Pengujian Hipotesis}

\section{a) Pengujian Hipotesis 1}

Hipotesis pertama yang akan diuji dalam penelitian ini adalah terdapat pengaruh positif Disiplin Belajar terhadap Prestasi Belajar Mahasiswa Program Studi Pendidikan Akuntansi Angkatan 2009 Fakultas Ekonomi Universitas Negeri Yogyakarta. Untuk menguji hipotesis tersebut digunakan analisis regresi sederhana. 
Tabel 1. Ringkasan Hasil Analisis Regresi Sederhana $\left(X_{1}-Y\right)$

\begin{tabular}{|l|c|c|c|c|c|c|c|}
\hline \multicolumn{1}{|c|}{ Sumber } & Koef. & $\mathbf{r}_{\mathbf{x} 1 \mathbf{y}}$ & $\mathbf{r}_{\mathbf{x} \mathbf{2}}^{\mathbf{2}}$ & $\mathbf{t}$ & $\mathbf{t}_{\mathbf{0 , 0 5}}(\mathbf{1 1 5})$ & $\mathbf{p}$ & Keterangan \\
\hline (Konstanta) & 2,032 & & & & & & $\begin{array}{c}\text { Ho tidak } \\
\text { diterima }\end{array}$ \\
\hline Disiplin Belajar & 0,020 & 0,587 & 0,345 & 7,780 & 1,984 & 0,000 & \\
\hline
\end{tabular}

Sumber: Data primer yang telah diolah

\section{a. Persamaan Garis Regresi}

Berdasarkan tabel di atas, maka persamaan regresi dapat dinyatakan dalam persamaan sebagai berikut:

$$
\mathrm{Y}=0,020 \mathrm{X}_{1}+2,032
$$

Persamaan tersebut menunjukkan bahwa nilai koefisien regresi bernilai positif sebesar 0,020 yang berarti jika nilai Disiplin Belajar $\left(\mathrm{X}_{1}\right)$ naik 1 satuan maka Prestasi Belajar $(\mathrm{Y})$ naik sebesar 0,020 .

\section{b. Koefisien Korelasi (r) dan Koefisien Determinan ( $\left.\mathbf{r}^{2}\right)$}

Hasil analisis regresi sederhana dengan satu prediktor menunjukkan koefisien korelasi (r) sebesar 0,587 dengan koefisien determinasi $\left(r^{2}\right)$ 0,345, hal ini berarti bahwa Disiplin Belajar mampu mempengaruhi 34,5\% perubahan pada Prestasi Belajar. Hal ini menunjukkan, masih ada $65,5 \%$ faktor atau variabel lain yang kemungkinan berpengaruh terhadap Prestasi Belajar.

\section{c. Pengujian Signifikansi Regresi Sederhana}

Pengujian signifikansi bertujuan untuk mengetahui keberartian variabel Disiplin Belajar terhadap Prestasi Belajar. Hipotesis yang diuji terdapat pengaruh positif Disiplin Belajar terhadap Prestasi Belajar Mahasiswa Program Studi Pendidikan Akuntansi Angkatan 2009 Fakultas Ekonomi Universitas Negeri Yogyakarta. Pengujian signifikansi dengan uji t diperoleh harga $t_{\text {hitung }}$ yang dihasilkan 7,780 , sehingga hipotesis yang menyatakan bahwa terdapat pengaruh positif Disiplin Belajar terhadap Prestasi Belajar Mahasiswa Program Studi Pendidikan Akuntansi Angkatan 2009 Fakultas Ekonomi Universitas Negeri Yogyakarta dapat diterima. Harga $t_{\text {tabel }}$ dengan taraf signifikansi 5\% sebesar 1,984. Hal ini berarti bahwa $t_{\text {hitung }}$ lebih besar dari tabel $(7,780>1,984)$, sehingga Disiplin Belajar mempunyai pengaruh positif dan signifikan terhadap Prestasi Belajar.

\section{b) Pengujian Hipotesis 2}

Hipotesis kedua yang akan diuji dalam penelitian ini adalah terdapat pengaruh positif Lingkungan Teman Sebaya terhadap Prestasi Belajar Mahasiswa Program Studi Pendidikan 
Akuntansi Angkatan 2009 Fakultas Ekonomi Universitas Negeri Yogyakarta. Untuk menguji hipotesis tersebut digunakan analisis regresi sederhana.

Tabel 2. Ringkasan Hasil Analisis Regresi Sederhana $\left(X_{2}-Y\right)$

\begin{tabular}{|l|c|c|c|c|c|c|c|}
\hline \multicolumn{1}{|c|}{ Sumber } & Koef. & $\mathbf{r}_{\mathbf{x} 2 \mathbf{y}}$ & $\mathbf{r}_{\mathbf{x} 2 \mathbf{y}}$ & $\mathbf{t}$ & $\mathbf{t} \mathbf{0 , 0 5}(\mathbf{1 1 5})$ & $\mathbf{p}$ & Keterangan \\
\hline $\begin{array}{l}\text { (Konstanta) } \\
\text { Lingkungan } \\
\text { Teman Sebaya }\end{array}$ & 2,674 & & & & & & $\begin{array}{c}\text { Ho tidak } \\
\text { diterima }\end{array}$ \\
\hline
\end{tabular}

Sumber: Data primer yang telah diolah

\section{a. Persamaan Garis Regresi}

Berdasarkan tabel di atas, maka persamaan regresi dapat dinyatakan dalam persamaan sebagai berikut:

$$
\mathrm{Y}=0,013 \mathrm{X}_{2}+2,674
$$

Persamaan tersebut menunjukkan bahwa nilai koefisien regresi bernilai positif sebesar 0,013 yang berarti jika nilai Lingkungan Teman Sebaya $\left(\mathrm{X}_{2}\right)$ naik 1 satuan maka Prestasi Belajar (Y) naik sebesar 0,013.

\section{b. Koefisien Korelasi (r) dan Koefisien Determinan $\left(\mathbf{r}^{2}\right)$}

Hasil analisis regresi sederhana dengan satu prediktor menunjukkan koefisien korelasi (r) sebesar 0,429 dengan koefisien determinasi $\left(\mathrm{r}^{2}\right)$ 0,184, hal ini berarti bahwa Lingkungan Teman Sebaya mampu mempengaruhi 18,4\% perubahan pada Prestasi Belajar. Hal ini menunjukkan, masih ada $81,6 \%$ faktor atau variabel lain yang kemungkinan berpengaruh terhadap Prestasi Belajar.

\section{c. Pengujian Signifikansi Regresi Sederhana}

Pengujian signifikansi bertujuan untuk mengetahui keberartian variabel Lingkungan Teman Sebaya terhadap Prestasi Belajar. Hipotesis yang diuji terdapat pengaruh positif Lingkungan Teman Sebaya terhadap Prestasi Belajar Mahasiswa Program Studi Pendidikan Akuntansi Angkatan 2009 Fakultas Ekonomi Universitas Negeri Yogyakarta. Pengujian signifikansi dengan uji t diperoleh harga thitung yang dihasilkan 5,097, sehingga hipotesis yang menyatakan bahwa terdapat pengaruh positif Lingkungan Teman Sebaya terhadap Prestasi Belajar Mahasiswa Program Studi Pendidikan Akuntansi Angkatan 2009 Fakultas Ekonomi Universitas Negeri Yogyakarta dapat diterima. Harga $t_{\text {tabel }}$ dengan taraf signifikansi 5\% sebesar 1,984. Hal ini berarti bahwa $t_{\text {hitung }}$ lebih besar dari $t_{\text {tabel }}(5,097>1,984)$, sehingga 
Lingkungan Teman Sebaya mempunyai pengaruh positif dan signifikan terhadap Prestasi Belajar.

\section{c) Pengujian Hipotesis 3}

Hipotesis ketiga yang akan diuji dalam penelitian ini adalah terdapat pengaruh positif Disiplin Belajar dan Lingkungan Teman Sebaya secara bersama-sama terhadap Prestasi Belajar Mahasiswa Program Studi Pendidikan Akuntansi Angkatan 2009 Fakultas Ekonomi Universitas Negeri Yogyakarta. Untuk menguji hipotesis tersebut digunakan analisis regresi ganda.

Tabel 3. Ringkasan Hasil Analisis Regresi Ganda $\left(X_{1} \& X_{2}-Y\right)$

\begin{tabular}{|c|c|c|c|c|c|c|c|}
\hline Sumber & Koef. & $\mathbf{R}_{\mathbf{y} 12}$ & $R^{2}$ y12 & $\mathbf{F}$ & $\begin{array}{l}F_{0,05} \\
(2 ; 114)\end{array}$ & $\mathbf{p}$ & Keterangan \\
\hline $\begin{array}{l}\text { (Konstanta) } \\
\text { Disiplin Belajar } \\
\text { Lingkungan } \\
\text { Teman Sebaya }\end{array}$ & $\begin{array}{l}1,866 \\
0,017 \\
0,007\end{array}$ & 0,625 & 0,391 & 36,618 & 3,090 & 0,000 & $\begin{array}{l}\text { Ho tidak } \\
\text { diterima }\end{array}$ \\
\hline
\end{tabular}

Sumber: Data primer yang telah diolah

\section{a. Persamaan Garis Regresi}

Berdasarkan tabel di atas, maka persamaan regresi dapat dinyatakan dalam persamaan sebagai berikut:

$$
\mathrm{Y}=0,017 \mathrm{X}_{1}+0,007 \mathrm{X}_{2}+1,866
$$

Persamaan tersebut menunjukkan bahwa nilai koefisien $\mathrm{X}_{1}$ sebesar 0,017 artinya, apabila nilai Disiplin Belajar $\left(\mathrm{X}_{1}\right)$ meningkat 1 poin maka nilai Prestasi Belajar (Y) akan meningkat sebesar 0,017 poin, dengan asumsi $\mathrm{X}_{2}$ tetap. Koefisien $\mathrm{X}_{2}$ sebesar 0,007 artinya apabila Lingkungan Teman Sebaya $\left(\mathrm{X}_{2}\right)$ meningkat 1 poin maka pertambahan nilai pada Prestasi Belajar (Y) sebesar 0,007 poin, dengan asumsi $\mathrm{X}_{1}$ tetap.

\section{b. Koefisien Korelasi (r) dan Koefisien Determinan $\left(\mathbf{r}^{2}\right)$}

Hasil perhitungan SPSS Statistics 16.0 menujukkan harga koefisien korelasi (R) sebesar 0,625 dan harga koefisien determinasi $\left(\mathrm{R}^{2}\right)$ sebesar 0,391. Nilai tersebut berarti 39,1\% perubahan variabel Prestasi Belajar (Y) dapat diterangkan oleh Disiplin Belajar $\left(\mathrm{X}_{1}\right)$ dan Lingkungan Teman Sebaya $\left(\mathrm{X}_{2}\right)$ sedangkan $60,9 \%$ dijelaskan variabel lain yang tidak diteliti dalam penelitian ini. 


\section{c. Pengujian Signifikansi Regresi Ganda}

Pengujian signifikansi bertujuan untuk mengetahui keberartian variabel Disiplin Belajar dan Lingkungan Teman Sebaya terhadap Prestasi Belajar. Hipotesis yang diuji terdapat pengaruh positif Disiplin Belajar dan Lingkungan Teman Sebaya secara bersamasama terhadap Prestasi Belajar Mahasiswa Program Studi Pendidikan Akuntansi Angkatan 2009 Fakultas Ekonomi Universitas Negeri Yogyakarta. Uji signifikansi menggunakan uji F, berdasarkan hasil uji $\mathrm{F}$ diperoleh $\mathrm{F}_{\text {hitung }}$ sebesar 36,618 sehingga hipotesis yang menyatakan bahwa terdapat pengaruh positif Disiplin Belajar dan Lingkungan Teman Sebaya secara bersama-sama terhadap Prestasi Belajar Mahasiswa Program Studi Pendidikan Akuntansi Angkatan 2009 Fakultas Ekonomi Universitas Negeri Yogyakarta dapat diterima. Jika dibandingkan dengan nilai $\mathrm{F}_{\text {tabel }}$ sebesar 3,09 pada taraf signifikansi 5\%, maka 36,618 > 3,09 ( $\mathrm{F}_{\text {hitung }}>\mathrm{F}_{\text {tabel }}$ ) sehingga Disiplin Belajar dan Lingkungan Teman Sebaya mempunyai pengaruh positif dan signifikan secara bersama-sama terhadap Prestasi Belajar.

\section{d. Sumbangan Relatif dan Sumbangan Efektif}

Berdasarkan hasil analisis yang tercantum dalam tabel di atas dapat diketahui bahwa Disiplin Belajar memberikan sumbangan relatif sebesar 74,29\% dan Lingkungan Teman Sebaya sebesar 25,71. Sumbangan efektif variabel Disiplin Belajar sebesar 29,06\% dan Lingkungan Teman Sebaya sebesar 10,06\%. Sumbangan efektif total sebesar 39,11\% yang berarti secara bersama-sama variabel Disiplin Belajar dan Lingkungan Teman Sebaya memberikan sumbangan efektif sebesar 39,11\% sedangkan $60,89 \%$ diberikan oleh variabelvariabel lain yang tidak dibahas dalam penelitian ini.

\section{Penutup}

\section{Kesimpulan}

a) Terdapat pengaruh positif dan signifikan Disiplin Belajar terhadap Prestasi Belajar Mahasiswa Program Studi Pendidikan Akuntansi Angkatan 2009 Fakultas Ekonomi Universitas Negeri Yogyakarta, dengan $r_{x 1 y}=0,587 ; r_{x 1 y}^{2}=0,345 ;$ dan $t_{\text {hitung }}=7,780$.

b) Terdapat pengaruh positif dan signifikan Lingkungan Teman Sebaya terhadap Prestasi Belajar Mahasiswa Program Studi Pendidikan Akuntansi Angkatan 2009 Fakultas Ekonomi Universitas Negeri Yogyakarta, dengan $\mathrm{r}_{\mathrm{x} 2 \mathrm{y}}=0,429 ; \mathrm{r}_{\mathrm{x} 2 \mathrm{y}}^{2}=0,184$; dan $\mathrm{t}_{\text {hitung }}=$ 5,097 . 
c) Terdapat pengaruh positif dan signifikan Disiplin Belajar dan Lingkungan Teman Sebaya secara bersama-sama terhadap Prestasi Belajar Mahasiswa Program Studi Pendidikan Akuntansi Angkatan 2009 Fakultas Ekonomi Universitas Negeri Yogyakarta, dengan $\mathrm{R}_{\mathrm{y}(1,2)}=0,625 ; \mathrm{R}_{\mathrm{y}(1,2)}^{2}=0,391 ;$ dan $\mathrm{F}_{\text {hitung }}=36,618$.

\section{Saran}

Berdasarkan hasil analisis, maka penulis memberikan beberapa saran sebagai berikut:

a) Saran untuk penelitian selanjutnya

Penelitian ini memberikan informasi bahwa Disiplin Belajar dan Lingkungan Teman Sebaya berpengaruh terhadap Prestasi Belajar sebesar 39,1\%. Hal ini menunjukkan bahwa Prestasi Belajar masih banyak dipengaruhi oleh faktor lain. Oleh karena itu, diharapkan dalam penelitian selanjutnya untuk mengetahui faktor-faktor yang mempengaruhi Prestasi Belajar selain yang diteliti dalam penelitian ini, misalnya faktor internal antara lain fisik/jasmani, kematangan fisik, kelelahan, psikologi berupa bakat, minat, kecerdasan, motivasi dan kemampuan kognitif maupun prestasi. Faktor eksternal meliputi lingkungan alam, lingkungan keluarga (cara orang tua mendidik, relasi antar anggota keluarga, suasana rumah, keadaan ekonomi keluarga, pengertian orang tua, latar belakang kebudayaan), lingkungan sekolah (metode mengajar, media pembelajaran, kurikulum, relasi guru dengan siswa, relasi siswa dengan siswa, disiplin sekolah, waktu sekolah, standar pelajaran di atas ukuran, metode belajar, tugas rumah), dan lingkungan masyarakat (kegiatan siswa dalam masyarakat, teman bergaul, bentuk kehidupan masyarakat)

b) Saran untuk mahasiswa

Secara umum Prestasi Belajar mahasiswa dipengaruhi oleh beberapa faktor. Dalam penelitian ini dipengaruhi oleh faktor Disiplin Belajar dan Lingkungan Teman Sebaya. Untuk meningkatkan Prestasi Belajar, mahasiswa harus dapat menimbulkan Disiplin Belajar dari kesadarannya sendiri agar dapat lebih memacu dan tahan lama untuk melakukan kegiatan belajar sehingga hasil yang diperoleh dapat maksimal. Belajar juga hendaknya dilakukan secara terus-menerus dan menjadikannya suatu kebiasaan yang rutin. Hal lain yang tidak kalah penting adalah perhatian mahasiswa terhadap mata kuliah itu sendiri, pada saat perkuliahan berlangsung sebaiknya mahasiswa memperhatikan penjelasan dosen, tidak mengobrol dan bercandaan dengan teman sebelahnya. 
c) Saran untuk dosen

Dosen sebaiknya berupaya untuk menumbuhkan dan meningkatkan Disiplin Belajar mahasiswa dan meminimalisir peran Lingkungan Teman Sebaya yang negatif dan menimbulkan merosotnya Prestasi Belajar mahasiswa. Untuk meningkatkan Disiplin Belajar mahasiswa dosen perlu memberikan pemahaman tentang disiplin dalam hal belajar dan memberikan pembinaan yang berlanjut yang menjadikan mahasiswa mempunyai kedisiplinan dalam dunia perkuliahan. Selain itu juga hendaknya dosen menciptakan suasana belajar mengajar yang menarik dan menyenangkan agar mahasiswa tidak merasa jenuh dan bosan, sehingga kegiatan mengobrol dan bercandaan dengan teman sebelahnya saat perkuliahan berlangsung dapat berkurang.

\section{E. Daftar Pustaka}

Abu Ahmadi dan Widodo Supriyono. (2004). Psikologi Belajar. Jakarta: PT Rineka Cipta.

Baharuddin, Esa Nur Wahyuni. (2009). Teori Belajar \& Pembelajaran. Jogjakarta: Ar-Ruzz Media.

Bhuono Agung. (2005). Strategi Jitu Memilih Metode Statistik Penelitian dengan SPSS. Yogyakarta: Andi Offset.

Devia Nur Fitriana. (2010). Pengaruh Lingkungan Teman Sebaya dan Motivasi Belajar Terhadap Prestasi Belajar Akuntansi Siswa Kelas X Program Keahlian Akuntansi SMK YPKK 2 Sleman Tahun Ajaran 2010/2011. Skripsi. Pendidikan Akuntansi FISE UNY.

Depdiknas (2003) Undang-Undang Sistem Pendidikan Nasional.

Hurlock, Elizabeth (2002) Perkembangan Anak. Jakarta: Erlangga

Malayu Hasibuan. (2002) Manajemen Sumber Daya Manusia. Jakarta: Bumi Aksara

Moenir, H.A.S. (2010) Manajemen Pelayanan Umum di Indonesia. Jakarta: Bumi Aksara.

Mudrajad Kuncoro. (2003). Metode Riset Untuk Bisnis dan Ekonomi : Bagaimana. Meneliti dan Menulis Tesis?. Jakarta : Erlangga.

Muhibbin Syah. (2008). Psikologi Pendidikan Dengan Pendekatan Baru. Bandung: Remaja Rosdakarya.

Muslim Fikri. (2011). Pengaruh Motivasi Belajar dan Disiplin Belajar terhadap Prestasi Belajar Mahasiswa Jurusan Kependidikan Islam Angkatan 2007 dan 2008 Fakultas Tarbiyah dan Keguruan UIN Sunan Kalijaga Yogyakarta. Skripsi. Fakultas Tarbiyah dan Keguruan UIN Sunan Kalijaga Yogyakarta. 
Nana Syaodih Sukmadinata. (2009). Landasan Psikologis Proses Pendidikan. Bandung: PT Remaja Rosdakarya.

Natalia Siwi Samawati. (2010). Pengaruh Disiplin Belajar dan Lingkungan Belajar terhadap Prestasi Belajar Akuntansi Siswa Kelas X Program Keahlian Akuntansi di SMK Negeri 1 Bantul Tahun Ajaran 2009/2010. Skripsi. Pendidikan Akuntansi FISE UNY.

Ngalim Purwanto. (2006). Psikologi Pendidikan. Bandung: PT Remaja Rosdakarya.

Peraturan Akademik Universitas Negeri Yogyakarta (2006).

Slavin, Robert E. (2008). Psikologi Pendidikan Teori dan Praktik. Jakarta: PT Indeks.

Septi Dwi Ariyanti Munawaroh. (2010). Pengaruh Perhatian Orang Tua dan Disiplin Belajar Terhadap Prestasi Belajar Akuntansi Siswa Kelas XI Ilmu Sosial SMA N 1 Kutowinangun Tahun Ajaran 2009/2010. Skripsi. Pendidikan Akuntansi FISE UNY.

Slameto. (2010). Belajar dan Faktor yang Mempengaruhinya. Jakarta: Rineka Cipta.

Sugihartono, dkk. (2007). Psikologi Pendidikan. Yogyakarta: UNY Press.

Sugiyono. (2007). Statistika untuk Penelitian. Bandung: Alfabeta. . (2009). Metode Penelitian Kuantitatif Kualitatif dan R\&D. Bandung: Alfabeta..

Suharsimi Arikunto. (2003). Manajemen Pengajaran Secara Manusiawi. Jakarta: Rineka Cipta. . (2009). Dasar-dasar Evaluasi Pendidikan. Jakarta: Bumi Aksara.

Cipta. (2010). Prosedur Penelitian Suatu Pendekatan Praktik. Jakarta: Rineka

Sumadi Suryabrata. (2002). Psikologi Pendidikan. Jakarta: PT. Raja Grafindo Persada.

Susilowati Andari. (2009). Pengaruh Motivasi, Minat, dan Lingkungan Teman Sebaya terhadap Prestasi Belajar Mahasiswa Akafarma Sunan Giri Ponorogo. Skripsi. Universitas Sebelas Maret Surakarta

Sutratinah Tirtinegoro. (2001). Anak Super Normal dan Program Pendidikannya. Jakarta: Bumi Aksara.

Sutrisno Hadi. (2004). Analisis Regresi. Yogyakarta: Andi Offset.

Umar Tirtahardjo, La Sulo. (2005). Pengantar Pendidikan. Jakarta: Pusat Perbukuan Depdiknas dan Penerbit Rineka Cipta.

UNY. (2011). Pedoman Penulisan Tugas Akhir Jurusan Pendidikan Akuntansi. Yogyakarta: UNY

Vembriarto. (2003). Sosiologi Pendidikan. Jakarta: PT. Gramedia Widia Sarana. 
Jurnal Pendidikan Akuntansi Indonesia, Vol. X, No. 1, Tahun 2012

Singgih Tego Saputro \& Pardiman

Halaman $78-97$

Wina Sanjaya. (2009). Strategi Pembelajaran Berorientasi Standar Proses Pendidikan. Jakarta: Kencana. 